\title{
Disciplinary Practices As Social Man- oeuvers: A Field Theory Alternative To Michael Burawoy's Typology Of KNOWLEDGE
}

\author{
JULIEN LANDRY
}

\begin{abstract}
In his call for more public sociology, Michael Burawoy presents a generic framework to describe disciplinary structures in the social sciences. This model is based on a fourfold typology of knowledge which has been criticized by many. However, alternatives have fallen short of providing a convincing articulation of the social organisation and meaning of the intellectual practices the original typology was trying to describe. The debate on public sociology did not bridge differences in analytical beliefs about knowledge production and thus could not be expected to build a consensual disciplinary orientation. The current paper builds on field theory, organizational sociology, and interview data to frame the practices identified by Burawoy as social manoeuvers (i.e. ways of utilizing and legitimating knowledge) within specific social fields. In so doing, the paper provides a framework that is more flexible, more empirically adequate, and congruent with the sociology of science and the sociology of intellectuals and experts.
\end{abstract}

Keywords: Disciplinary practices, public sociology, knowledge production, intellectuals, experts

Résumé. Dans son plaidoyer pour la sociologie publique, Michael Burawoy présente un cadre générique pour décrire les structures disciplinaires en sciences sociales. Plusieurs commentateurs ont critiqué la quadripartition typologique $\mathrm{du}$ savoir que propose son modèle. Cependant, les tentatives de le remplacer n'ont pas fourni une articulation convaincante du sens et de l'organisation sociale des pratiques intellectuelles abordées par la théorie originale. Le débat sur la sociologie publique n'a pas su concilier les diverses conceptions relatives à la production de connaissance. Par conséquent, il ne put construire une orientation disciplinaire consensuelle. Le présent article s'appuie sur la théorie des champs, la sociologie des organisations ainsi que des entretiens pour avancer une conception des pratiques décrites par Burawoy comme des coups (c.-à-d. des façons de mobiliser et de légitimer la connaissance) dans des champs sociaux spécifiques. 
À ce titre, cet article fournit un cadre qui est plus flexible, plus empiriquement adéquat et compatible avec la sociologie des sciences et la sociologie des experts et des intellectuels.

Mots clés: Sciences sociales, sociologie, sociologie publique, recherche, intellectuels, experts

\section{INTRODUCTION}

D) uring his presidential address at the annual congress of the American Sociological Association in 2004, Michael Burawoy presented a framework that provoked an extensive debate on the division of academic labour (Burawoy 2005a). His typology of research and program for sociology were discussed in various journals and edited volumes. Social Forces, Social Problems, Critical Sociology, The American Sociologist, The British Journal of Sociology, Sociology, and the Canadian Journal of Sociology, among others, filled their pages with analysis, commentary, and heated exchange. Contributors weighed in on Burawoy's call to further enable public sociology and mobilize the discipline in defence of civil society. They also examined his belief that the "reciprocal interdependence" between critical, professional, policy, and public sociology could unite the discipline and renew its "moral fiber" (Burawoy 2005a: $5,15)$.

Sociologists discussed the plausibility of Burawoy's project, its potential pitfalls, and its conceptual shortcomings. Scholars favouring the collaborative, engaged, and "bottom-up" style of Burawoy's cherished "organic public sociologists" were enthused by his disciplinary program (e.g. Katz-Fishman and Scott 2005). Others discussed alternative ways of conceiving public sociology (e.g. Helmes-Hayes 2009; Mesny 2009) or summarized institutional conditions for its development (e.g. Sprague \& Laube 2009; Stacey 2007). "Critical sociologists" decried the hegemony of American professional sociology, warned against the marginalization of public sociology, or raised concerns over whose standpoint would inform public engagement (e.g. Acker 2005; Baiocchi 2005; Brewer 2005; Collins 2007; Ghamari-Tabrizi 2005; Glenn 2007; Hays 2007; Piven 2007). In contrast, those whom Burawoy (2005c: 152) would classify as "professional sociologists" looked to orient the discipline towards a cohesive knowledge base and argued against the expansion of sociology's public moral commitments (e.g. Boyns and Fletcher 2005; Brint 2005; Goldberg \& van den Berg 2009; Massey 2007; Nielsen 2004; SmithLovin 2007; Stinchcombe 2007; Tittle 2004; Turner, 2005). 
The debate featured sociological commentary on sociology and on the debate as an extension of the discipline's structure. It also illustrated a striking degree of discordance surrounding various depictions of academic roles and postures. For many, the distinctions between types of sociology proposed by Burawoy were not sound or did not register with their own experience (e.g. Abbott 2007; Creese et al. 2009; Ericson 2005; Kalleberg 2005, 2012; Patterson 2007; Wallerstein 2007). A team of Canadian sociologists illustrated how some of Burawoy's central distinctions had little analytical breadth outside of his politically charged program (McLaughlin et al. 2005; McLaughlin and Turcotte 2007). Burawoy's theory of the discipline's structural allegiance to civil society was criticized for its performativity (Nielsen 2004). Likewise, many felt that his interpretation of modern society idealized the civil sphere and demonized states and markets (e.g. Beck 2005; Brady 2004; Braithwaite 2005; Brint 2005; Calhoun 2005; Hall 2005; Patterson 2007).

Regardless of attempts to study the distribution of Burawoy's knowledge "types" (Brym and Nakhaie 2009; Kowalchuk and McLaughlin 2009; Mochnacki et al. 2009) and despite analytical revisions to the model itself (e.g. Kalleberg 2005; 2012; McLaughlin and Turcotte 2007; Morrow 2009), the debate has not produced a satisfying analysis of these practices. To what extent do they correspond to distinct logics of knowledge production and dissemination, and how are they situated within disciplinary structures?

These questions are important because they motivate our conceptions of what disciplinary practices are, as well as what they can and should be. They have led me to build upon sociological literature and on interventions in the public sociology debate to theorize the structure of social scientific disciplines and the modes of intervention they enable. Additionally, to understand how these practices are semantically organized, I conducted twenty-five semi-structured interviews with sociologists, historians, and economists from Quebec and New-Brunswick universities.

The first section of this article describes Burawoy's theory of social scientific knowledge production and critiques the functions he ascribes to disciplinary practices. In the second section, I discuss alternatives to Burawoy's typology (they constitute rare attempts to provide replacement frameworks rather than commentary) and use field theory and organisational sociology to account for both the meaning of disciplinary practices and their grounding in social space. I argue that disciplinary practices can be understood as tasks and postures, as described by Kalleberg $(2000 ; 2005 ; 2012)$, but that these do not acquire their meaning in the functional "role-set" of academia. Rather, they are manoeu- 
vers which take shape within and between distinct spheres of action: the scientific field, the university field, and an assortment of extra-academic fields (Bourdieu 1975; Fournier 1985; Gingras and Gemme 2006; Gingras 1991; Warren 2009). The empirical section of this paper then serves to demonstrate how this framework can refine Burawoy's distinctions. I use interview data to argue that professional, critical, public, and policy interventions offer ways of utilizing and legitimating knowledge which conform to different contexts of control.

This contribution will help improve our understanding of public sociology and other disciplinary practices. With the aid of historical and theoretical literature as well as empirical data, this article further deconstructs contentious distinctions in Burawoy's typology. It also clarifies the properties and the social organisation of disciplinary tasks using categories that can accommodate institutional and historical differences. It does this by developing a framework that accounts for how disciplinary practices assimilate meaning as well as material and symbolic resources from specific fields. This allows us to understand constraints, incentives, and localised expressions of control in knowledge production and dissemination.

\section{Burawoy's Theory Of Disciplinary Organisation}

Burawoy's model organises sociology (or any discipline) around four modes of knowledge production. Professional sociologists solve scientific puzzles defined by their peers, critical sociologists participate in academic debates over the values and assumptions of professional sociology, policy sociologists bring sociological knowledge to bear on the needs of clients, and public sociologists engage in public discourse over political or moral matters. Their differentiation relates to two questions which link "forms of knowledge" to sources of "legitimacy" and "accountability" (Burawoy 2005a: 16). The first is "knowledge for whom?" The other is "knowledge for what?"

In terms of their designated publics, professional and critical sociology have academic audiences, while policy and public sociology have extra-academic audiences. The second question leads to a distinction between "instrumental" and "reflexive" knowledge (Burawoy 2004: 1606; 2005a: 11). Professional and policy sociology produce "instrumental knowledge" because they seek to find solutions to scientific problems defined by peers or to practical problems formulated by extra-academic clients. Critical and public sociology are "reflexive" because they examine the fundamental goals and values of the discipline or of society. 
Keeping to the "“means-end" orientation" of "normal science", professional sociology does not question its "foundations" or its "value premises" (Burawoy et al. 2004: 105). Instead, professional sociologists seek to produce "theories that correspond to the empirical world" by solving "puzzles" or "lacunae, anomalies, and contradictions" which are defined within the scope of research programs (Burawoy 2004: 1609; 2005a: 16; 2009a: 871). This "substantive professionalism" is also charged with training new sociologists. It is contrasted with "formal professionalism" which manages and protects substantive professionalism with processes of "collective self-regulation" (Burawoy 2009a: 879-880). Graduate school and career exigencies mold sociologists to the requirements of professional sociology and often kill their original "moral impetus" (Burawoy 2005a: 5). Conversely, professional sociology provides "legitimacy and expertise" to public and policy sociology (Burawoy 2005a: 10).

Critical sociology reforms the "normative" and "descriptive" foundations of the discipline (Burawoy 2005a: 10). It supplies the moral roots of public sociology and criticizes policy sociology for "putting values up for sale" (Burawoy 2004: 1609, Burawoy et al. 2004: 105). Most importantly, since professional sociology cannot question its own assumptions, it is the role of critical sociologists to do so (Burawoy 2004: 1609; Burawoy 2009a: 881). Burawoy finds critical sociology in the works of scholars like Robert Lynd, C. Wright Mills, and Alvin Gouldner as well as in the conceptual tools of "feminism", "queer theory", "race theory", and other critical interdisciplinary enterprises (Burawoy 2004: 1609; Burawoy 2005a: 10). In more general terms, however, critical sociology simply provides new veins of investigation that rely on "alternative foundations" (Burawoy 2005a: 10). As such, critical knowledge can be found in the heterodox movements of any discipline (Burawoy 2004: 1616), and: "what was professional sociology yesterday can be critical today" (Burawoy 2005a: 16).

Policy sociology is concerned with the production of "concrete" and "pragmatic" knowledge for the narrow needs of "clients" or the broad dictates of "patrons" (Burawoy 2004: 1608; 2005a: 16). It is "instrumental" because it seeks to solve "problems" or justify existing solutions (Burawoy 2005a: 9). Policy sociology can be "sponsored" or "contractual" when clients partially or unilaterally define the terms of research. It can also be "advocacy" research if it is produced according to the researcher's own initiative and problems (Burawoy 2009a: 878). These research relations involve different extra-academic actors ranging from business and state organisations to small and large non-governmental organizations (Burawoy 2004: 1608). 
Public sociology engages in dialogue with various publics on matters relating to the "basic values and goals of society" (Burawoy 2009a: 871). Burawoy (2004: 1607; 2005a: 7; 2009a: 875-877) distinguishes between an "elite" and a "grass root" public sociology. The first is "traditional public sociology". It addresses mainstream publics through books, news media, and other forms of dissemination that maintain a distance with the audience. The second is "organic public sociology". It interacts directly and sometimes collaboratively with specific groups. Burawoy (2004:1608; 2005a: 9) believes teaching should be an organic public sociology, building "dialogue" with students, making their "private troubles into public issues" and allowing them to "become the ambassadors of sociology to the wider world".

Burawoy infuses flexibility into this model by showing that the inner complexity of professional, critical, policy, and public sociology periodically brings them closer together. Each type of sociology reproduces the tensions found at the disciplinary level by connecting to academic and extra-academic concerns or by exhibiting moments of reflexivity and instrumentalism (Burawoy 2005a: 13). Sociological practices can "straddle" different types of knowledge (Burawoy 2005a: 11). For example, there is "no watertight distinction" between public and policy sociology (Burawoy 2004: 1608) and they often "turn into" each other (Burawoy 2005a: 9).

The relative weight of each type of sociology can also vary historically and geographically. According to Burawoy (2005c: 156-159) American sociology went from a strong public engagement to the confines of academic professionalism. The instrumental axis is dominating American and Eastern European sociology while public sociology is mostly found in community colleges or in the global south (Burawoy 2005a: 19-20). Burawoy's types are also distributed differently in other disciplines. Economics and political science are aligned with instrumental knowledge, philosophy has an advantage in representing critical postures, and sociology and anthropology share a proclivity for reflexive public knowledge (Burawoy 2004: 1615).

This fluidity is where Burawoy's inspiration from field theory is most apparent. The discipline is not only a "division of labour", but also a "field of power" (Burawoy 2005a: 6). His four sociologies correspond to hierarchized positions that compete over disciplinary resources. On one level, individual researchers practice different kinds of sociology at different moments in their career. On another level, these practices are structured and distributed within the discipline as a field (Burawoy 2005a: 13). Practitioners perceive the discipline from their own standpoint and tend to reduce the other types to their potential pathological 
forms (i.e. professional sociology's "self-referentiality", policy sociology's "servility", critical sociology's "dogmatism", and public sociology's "faddishness") (Burawoy 2004; 2005a: 16; see also 2007: 245).

Burawoy's disciplinary project is designed to counter these antagonisms and control these pathologies. He would unite the discipline through a shared ethos recognising the "reciprocal interdependence" between all forms of sociology (Burawoy 2005a: 15). He envisions an "organic solidarity" (Burawoy 2005c: 159) where forms of sociology maintain their autonomy, but also build "fruitful interplays" (Burawoy 2004: 1611). In this respect, both critical and public sociology serve as the "conscience" of the other two (Burawoy 2005a: 10). They are to be safely institutionalised in academia where they can coexist with a hegemonic, rather than despotic, professional sociology (Burawoy 2005a: 18).

Burawoy's (2004: 1604; 2005a: 6) call for public sociology is formulated on the backdrop of a "scissor movement" opposing the discipline's move to the left and the rest of society's shift to the right. Public sociology's extra-academic and reflexive function has a crucial role in the defence of social justice and civil liberties, while critical sociology is called to infuse public sociology with its critical moral edge (Burawoy 2005b). In fact, Burawoy (2005c: 152; 2007) hopes that "third wave sociology" will have the entire discipline mobilize to help civil society resist expanding markets and complicit states. According to him, sociology's origins has constituted this as its "raison d'être" for it studies social phenomena from a standpoint preoccupied with the welfare of the civil sphere (Burawoy 2005a: 24; 2009b: 190).

Burawoy's typology offers a comprehensive look into the internal differentiation of disciplines and their links with other social spaces. My main contention with his theory is that it combines generic and analytical categories with contingent and normative accounts. The distinction between reflexive and instrumental knowledge is normative and not conducive as an "analytical category" (McLaughlin et al. 2005: 144). Instrumental knowledge's inability to question itself conveniently legitimates the remaining types. Analogously, his view of pubic sociology as engaged in dialogue on the direction of society, and his depiction of critical sociology as the watchdog of sociological knowledge are too constraining. Could they not be found striving for different goals? Moreover, defining them as "reflexive" hides their interactions with "market/ audience forces" and "academic competition" (McLaughlin et al. 2005: 142-143). I believe the functions he assigns to forms of sociology relate to the meaning they take within his disciplinary program rather than to actual practice. 
These problems make it difficult to distinguish each type. First, Burawoy broadly describes critical knowledge as a space for holders of alternative assumptions poised to challenge the dominant paradigms. Yet, in other instances, it is defined as constitutively critical and morally engaged. This places the theory in a double bind. If the latter is the proper definition it would not mark a divide between reflexive and instrumental knowledge, but instead reiterate the classical contrast between "mainstream" and "critical" sociology (Davies 2009). In fact, the goal of what is known as "critical sociology" is to bring critical perspectives to bear upon power relations and forms of life in modern society, not to question the foundations of professional sociology (Calhoun 2005). If the broader definition is right, and Marxist, feminist, queer, and race theories are only circumstantially "critical", then it is unclear how they differ from professional sociology (Kalleberg 2012; McLaughlin et al. 2005). Researchers who question the foundations of research programs do not necessarily operate under a different logic than those who contribute to the advancement of knowledge.

Policy and public sociology are also ambiguous. Creese et al. (2009) have noted that interdisciplinary fields of inquiry, such as feminist research, comprise critical and professional research programs that fuel both policy and public debate. Similarly, Patterson (2007) argues that contractual research can lead to knowledge that is funded, oriented, and critically reflexive. Burawoy's model can accommodate this. Public sociologists can capture the attention of decision makers and enter the realm of policy (Burawoy 2005a: 9-10), and policy sociologists can make "principled interventions" when they retain their ability to adopt a "critical stance" (Burawoy 2010: 13). However, these accounts are more congruent with the "inner complexity" of each form of sociology than with the ideal types themselves. Burawoy successfully demonstrates how research can engage in different relationships and address a variety of audiences. He is less convincing in advancing that a divide between reflexive and instrumental knowledge explains this variation. This leaves us with a need to account for the meaning of these practices and their grounding in disciplinary structures.

\section{Disciplines As Institutional Forms Between Social Fields}

Criticism of Burawoy's model has led some scholars to rethink his distinctions. A team of Canadian sociologists recommends delimiting disciplinary tasks by identifying their audiences (McLaughlin et al. 2005; McLaughlin and Turcotte 2007). They drop the instrumental and reflex- 
ive divide and frame critical sociology as a heterodox sector of professional sociology defined as knowledge production for peers. Similarly, they describe public sociology as addressing various publics and policy sociology as speaking to clients and decision makers in specific sectors. This conceptualization has the advantage of highlighting various groups with which the social scientist can interact while eliminating some of Burawoy's less probing distinctions. However, it does little to clarify the meaning of these practices beyond identifying their audiences.

Raymond A. Morrow (2009) also presents a revision of Burawoy's classification which abandons the reflexive and instrumental divide. He displaces critical sociology to make room for "social theory", which he defines as "systematic reflexive theorizing" stemming from "non-empirical" or "quasi-empirical" traditions whose "intellectual function" is to question other sociological practices (Morrow 2009: 58, 61-62). He then frames extra-academic sociologies as "competing strategies for combining means and ends" along a continuum of radical and conventional interventions. This allows Morrow to highlight the difference between narrowly "technocratic" and "liberal enlightenment" policy knowledge (Morrow 2009: 62-63). Public sociology is introduced as preoccupied by a longer time frame and as more inclined to discuss the ends of state policy (i.e. traditional public sociology) or the means for protecting civil society (i.e. organic public sociology). Morrow's continuum further deconstructs the division between instrumental and reflexive research. His revision is based on epistemic distinctions which give more adequate meaning to Burawoy's categories. However, his alternative "types" remain contingent to specific intellectual traditions. It is unclear why they form pertinent distinctions apart from the functional role they play in a normatively designed "division of labour" or a "post-Enlightenment" historical project (Morrow 2009: 65).

The above discussion disputes Burawoy's assumptions and sheds light on the meaning of disciplinary roles. However, to understand these practices more clearly, I reframe them as manoeuvers within and between social fields. Field theory stems from the work of sociologist Pierre Bourdieu (for an overview see Wacquant 1989). It describes fields as differentiated spheres of action constituted by interacting "agents" (individuals, groups, and institutions) that compete over capital, or socially valued resources that can be stored, transformed, mobilized, and exchanged. Each field houses a struggle over the specific type of capital that they generate. This capital is normally a variation of four generic kinds: economic capital (financial assets), social capital (accesses and contacts), cultural capital (recognised knowledge and certifications), and symbolic capital (authority or prestige based on reputation or titles 
derived from other forms of capital). The struggles over these resources are constitutive of the normal activities in the field. The definitions of these practices are also the objects of struggles, and they determine whose work will produce recognition or success. Although they practice a common activity (and share a commitment to it), agents are invested in different positions that distribute interests and structure power relations within the field. The structure of a field and the definition of its practices are historically determined by past struggles which have shaped the distribution of capital. In these struggles, dominant players (institutions and individuals who have accumulated more capital) are better equipped to impose the rules of the field and a definition of its stakes and aims.

Jean-Philippe Warren (2009) provides the first explicit use of field theory to reinterpret some of Burawoy's distinctions. According to Warren sociology is structured along three dimensions of practice and recognition: "professional", "descriptive", and "political". His historical narrative of the development of Quebec sociology highlights how sociologists balance aims and roles that are either 1) career oriented, 2) preoccupied by truth and knowledge, or 3) politically motivated. Sociologists of different periods combine professional recognition, knowledge for its own sake, and political activism in varying degrees. Borrowing from Fournier (1985), Warren (2009: 805) describes the discipline and these aims as structured by three fields: "institutional", "scientific", and "societal". The main strength of Warren's contribution is to show how the disciplinary practices described by Burawoy relate not to a "division of labour" but to a "structural division" pertaining to the "relative autonomy" of three social fields (Warren 2009: 805). However, his portrayal of the discipline as composed of professional, descriptive, and political practices is too general. I build upon his analysis by directly addressing the meaning of disciplinary tasks and by implementing a more detailed conceptualisation of the notion of discipline.

Ragnvald Kalleberg's $(2005 ; 2012)$ contributions to the public sociology debate provides a more in depth articulation of disciplinary practices. He views disciplines as groupings of five "institutional programmes" that serve different functions and compose the "role-set" of research universities (Kalleberg 2000: 230-231). His response reinterprets Burawoy's distinctions into this framework (Kalleberg 2005: 388; 2012: $43-44,48)$. "Research programmes" actualize the role of the professor as "researcher", and the disciplinary task of contributing to academic literature. These programs correspond to both professional and critical sociology in Burawoy's typology. "Teaching and study programmes" are tasked with the education and training of students at different levels and incorporate the professor's role as "teacher". "Dissemination and 
public-discourse programmes" are tasked with promoting "democratic discourse" as well as "scientific and cultural literacy". They support the role of the academic as "popularizer and debater" or "public intellectual" and correspond to Burawoy's traditional public sociology. "Expert programmes" strive to produce knowledge or train professionals to the benefit of "users". This role of the academic as "expert" assimilates both organic public sociology and policy sociology. "Self-governance programs" insure the functioning of departments, journals, associations, and other disciplinary institutions. These tasks are similar to Burawoy's (2009a: 880) "formal professionalism". However, for Kalleberg "gatekeeping" practices are dispersed in distinct moments of research, education, and self-governance programs (Kalleberg 2012: 47).

The five programs illustrated by Kalleberg successfully ground disciplinary tasks within an institutional structure. However, his model is too functionalist in explaining disciplinary practices through a fixed "roleset". This ignores an important contribution of field theory in thinking disciplinary logics, namely that different definitions of disciplinary tasks can compete for legitimacy and dominance (Bourdieu 1975). Disciplinary practices can be situated more adequately when we recognize research universities as fields colonized by scientific networks (Gingras 1991; Gingras and Gemme 2006) and entertaining various relationships with other fields (Fournier 1985; Warren 2009).

The university discipline should be understood historically as a specific institutional arrangement (Whitley 2000). As a unit of production for scientific knowledge, it is a construct that emerged in the $19^{\text {th }}$ century with the incorporation of research within institutions of higher learning (first in Prussia then elsewhere). The university discipline eventually became the principal organisational unit for scientific intellectual fields. Each discipline, at least ideal-typically, constitutes a self-governed system for the production, evaluation, dissemination, and appropriation of knowledge as well as socialization to research.

An essential feature of science as a form of cultural production is that its product (namely the scientific article) is consumed by producers themselves and used in their own innovation process (Whitley 2000). The institutional task of scientists is to produce new knowledge, and the primary stake in this activity is getting one's contribution recognized as innovative and significant. In this sense, and following Bourdieu (1975), the scientific field structures a form of competition that is simultaneously scientific and social. These are precisely the means by which the researcher acquires recognition, institutional security, prestige, celebrity, and other forms of material and symbolic resources. Agents compete to secure "scientific competence" and "authority" understood as a "tech- 
nical capacity" and a "social power" that provides the means to "speak and act with legitimacy" in regards to "matters of science" (Bourdieu 1975: 91-92).

The university discipline as an institutional innovation owes its success in part to its ability to simultaneously supply employment, forge research networks, and deliver training programs (Whitley 2000). The constitution and transposition of the Prussian university model therefore implied the transformation of the university's role from general education (as ordained by medieval tradition) to both education and research. From its onset, the implementation of a research imperative provoked a power struggle between a new generation of scientists and an old guard of university educators. Traditional professors saw this new norm as contouring pedagogy and collegiality (Turner 1971: 167-182). This lasting rivalry between education and research generates other oppositions, such as between generalists and specialists, and ultimately refers to struggles for the legitimate definition of the professors' tasks (Gingras 1991: 50). These struggles are the mark of the colonization of the university field by the scientific field (Gingras 1991; Gingras and Gemme 2006).

The social sciences found their modern institutional footing between the $19^{\text {th }}$ and the $20^{\text {th }}$ century, but in many countries and for certain disciplines they only emerged in the decades after World War II. The dissemination of the Prussian university model provided the material basis for the reproduction of these disciplines and their scholarly communities. However, the autonomy of these sciences has never been certain. The social sciences were constitutive of the political, social, and economic reform movements of the $19^{\text {th }}$ century. From their onset, they were solicited to tackle the then pressing "social question" tied to the deterioration of living standards and work conditions brought upon by industrialization and urban blight (Wittrock 2003: 80). The orientations of many disciplinary programs derive from this context of reform. In any case, the imperfect autonomy of the social sciences enables researchers to play various roles.

Field autonomy means that each field is organised around the struggles for a specific type of capital. It also means that the standards relative to the distribution of resources and rewards are defined by actors within the field. However, fields are thought of as being relatively autonomous and unequally so. Independence is generally imperfect and agents in various social spaces often interact with each other by sharing goals and by transferring or converting forms of material and symbolic capital (Bourdieu 1999: 26-27). Disciplines only partly form autonomous intellectual units dedicated to the production of knowledge for peers (Bourdieu 1975). Their institutionalisation within universities 
(Gingras 1991; Gingras and Gemme 2006) and the roles that these establishments incorporate (Kalleberg 2000) allow researchers to intervene in different fields as scientists, teachers, experts, or intellectuals. Hierarchal structures within universities, research institutions, and disciplinary associations also provide settings for professional mobility controlled by gate-keeping practices and processes of self-governance.

Reframing Fournier (1985) and Warren's (2009) threefold repartition of disciplinary structure allows us to situate 1) intellectual arenas of autonomous knowledge production, 2) institutional arrangements that provide education to students and employment to researchers, and 3) dissemination practices that give meaning to intellectual interventions and expertise. The roles and postures of university professors as identified by Kalleberg (c.f. supra) can then be situated as social manoeuvers within these fields. This allows us to identify forms of dissemination (within specific programs), modes of gate-keeping and recognition, and locales of self-governance (Figure 1). Major extra-academic fields can be specified. Intellectuals and experts often engage with political, bureaucratic, economic, and media fields (Medvetz 2012). They also interact with other elites in the "field of power", where forms of capital are hierarchized, and where the authority of their cultural capital is compared to political and economic power (Bourdieu 2011). However, the general caption of "societal fields" is useful because smaller, more specific, fields are often analytically constructed by field theorists to capture pertinent agents and stakes.

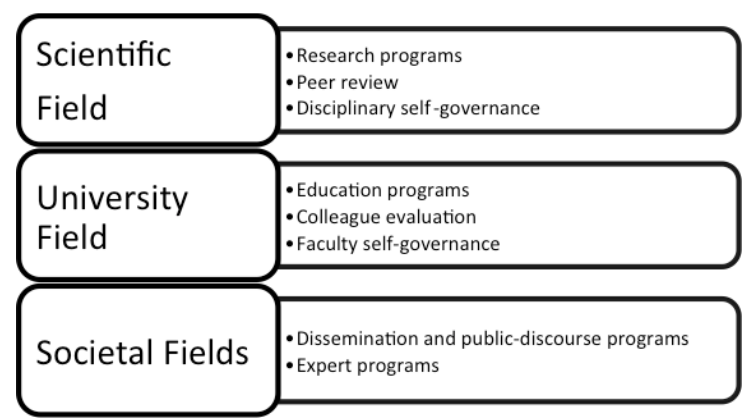

Figure 1: Disciplinary Structures

\section{EMPIRICAL INVESTIGATION}

To further articulate the meaning of interventions within scientific, university, and societal fields, the following sections will discuss an analy- 
sis of twenty five interviews conducted in 2011 with sociologists $(n=9)$, economists $(\mathrm{n}=5)$ and historians $(\mathrm{n}=11)$. These disciplines offer various views of the social sciences. Whereas much of sociology harbours research programs with concerns for political and critical analysis, economics is associated with disciplinary isolation and technical interventions. History is often regarded as a scholarly discipline, but its relatively jargon free writing and its heavy use of books are conducive to significant public exposure.

The relatively flat institutional landscape of Canadian universities (McLaughlin 2005), the country's relationship with the United States (Gingras and Warren 2006), and language preferences in Quebec (Godin 2002) shape institutional dynamics and publication and citation patterns. Francophone researchers are strongly influenced by sociology from France and often publish in French speaking venues. Dissimilar political contexts and different theoretical and critical traditions likely shape the relative weight of disciplinary practices in Quebec and the rest of Canada (Brooks and Gagnon 1994). The same could be said about the configurations of media landscapes. That being said, the arguments in this paper are meant to be upstream from such questions. The goal is to engage the matter on the same level as Burawoy's generic model.

Semi-structured interviews were conducted with Francophone $(n=9)$ and Anglophone $(\mathrm{n}=16)$ professors from Quebec $(\mathrm{n}=16)$ and New-Brunswick $(\mathrm{n}=9)$ universities. New-Brunswick provided smaller universities where publishing requirements are less important. Quebec was ideal to contact researchers from major Francophone and Anglophone institutions. Since academic rank can influence the meaning of disciplinary tasks for one's career, the sample comprised of professors with tenure track $(n=5)$, newly acquired tenure $(n=2)$, and tenured positions $(n=18)$.

The sample only included testimony from three female professors, creating a potential bias. Gender in science is often related to stratification, evaluation bias, and the incidence of parenthood on careers (e.g. Knobloch-Westerwick et al. 2013; Lincoln et al. 2012; Stack 2004; Wennerås and Wold 1997). Additionally, in some disciplines woman may be more likely to publish books and favour qualitative and constructivist methods (Mallard et al. 2009; Clemens et al. 1995). However, this does not seem to be a critical shortcoming of the study. The level of analysis is sufficiently general, primarily institutional, and about practices rather than outcomes. Given the scope of the study, I would not expect fundamentally dissimilar practices to emerge with a broader sample.

This inquiry collected discourse on research, teaching, evaluation, dissemination, grantsmanship, and other aspects of a professor's career. The content analysis of the transcripts was performed in Atlas Ti. The discourse was not analysed as explaining social facts but rather as being 
explained by them (i.e. as traces of social structures). In other words, the meaning of the activities described was understood as being relative to categories forged in socially organised spaces of practice (Sabourin 2003). A systematic description of the content (by categorising differences in meaning) was done prior to the analysis to minimize the risks of misinterpretation and confirmation bias (Hamel 2006).

Two sets of categories were highlighted, those pertaining to the legitimation of disciplinary practices and those used to explicate the practices themselves. Defining which activities comprise meaningful and legitimate tasks is an important stake within most fields. Social actors give value to specific activities using categories relative to the goals negotiated within the fields involved. Because of this, discourse on the goals and ends of research exemplifies how the meaning of disciplinary practices is tied to the relative autonomy of scientific, university, and societal fields. Disciplinary practices are then understood by actors through practical categories that give meaning to the material and symbolic capital they use in specific fields. Consequently, the categories used to describe practices designate the resources needed to accomplish them. They also exemplify how these tasks fit into field dynamics.

\section{The legitimation of disciplinary practices within and between social fields}

Fields provide specific categories for conferring meaning to disciplinary tasks. In the interviews, legitimation strategies relative to the autonomy of the scientific field described knowledge production as an end in itself or as a means to advance research programs:

"Understanding things better is a good thing whether it's understanding [object of study] or byzantine manuscripts, or whatever the case may be, that's what universities do so I think understanding things better is a good thing period" [11-sociologist].

"The work that we're supposed to do here at the university is to push back the frontiers of knowledge" [23-historian].

In other instances, interviewees gave meaning to research in a way that signaled the field's relations with its environment. Where immediate application was not the goal, research was described as having an intermediated impact:

"You know other researchers may pick up this analysis and do something very different with it and where it has a much broader or more popular application, because we don't do research in isolation, this is an ongoing conversation" [15-sociologist]. 
"It's an indirect participation because I can see how ideas that come out in academic journals, especially good ideas, can in good conditions "trickle down", as we say in English, into the public debate and eventually influence the policies that are taken" [25-economist - translated from French].

Likewise, academic problems were not perceived as necessarily divorced from worldly concerns and some voiced their preference for useful or relevant knowledge:

"Almost everything we do is policy relevant so the questions are of academic interest, but they're of academic interest mainly because they're of policy interest" [24-economist].

"I have to do something that I can see, that will translate into something useful" [13-sociologist].

The role of extra-academic fields as sources of meaning for the legitimation of research is apparent in categories relative to social relevance and utilization. This line of discourse is central to the preoccupations of investors, government officials, and university administrators. Academic literatures have championed its cause by studying knowledge utilization and encouraging its development (e.g. Böhme et al. 1976; Gibbons et al. 1994; Etzkowitz and Leydesdorff 2000; Nowotny et al. 2001). Regardless of whether they were understood by interviewees as political, educational, or technical in nature, public interventions, applied research, and community collaborations were tied to preoccupations over relevance, impact, or moral obligation:

"I see these as really important topics, and I want to help create better government, I want to help create a better Canada... a better country. And I know that sounds flakey, but that's what sort of motivates my research" [20-sociologist].

"I guess I see a moral end to history [...] I think the ends of it should be moral in the sense of being honest with what a culture is and where it comes from. And I see that as an end in itself [...] without which very negative outcomes of historical amnesia become possible [...]. I find that to be deeply problematic because it's not historically accurate, and also because it has a quite vicious effect on society" [9-historian].

"[The evaluation of public policies] has a value for the general public. I find that it is in the interest of the general public, and of mine, that there are researchers who are asking themselves these questions" [7-economist - translated from French]. 
"A lot of time in oral history the emphasis is on collection or preservation, right. We have to record these stories because these people are dying and we'll lose the story [...]. People have to know in the future, and that impulse is very strong" [16-historian].

Social relevance and utility can be framed in relation to different goals relative to domains such as business, governance, and social justice. In fact, these ends were sometimes pitted against each other by interviewees:

"Many universities, you only need to look at their website, they have an "industry-university relations officer", something like that. There are very few universities that, like [name of university], have a "service to the community" [...]. That in my opinion is unethical. It is inconceivable, and I will always be opposed to this and criticize this" [21-sociologist translated from French].

However, these goals share meaning by legitimating research through the ends of other fields. They refer to practices that join academic and societal ends:

"In an ironic kind of way, part of what we were demanding in the late sixties about relevance and trying to make the university be involved in its community is very much a part of what actually is driven by other aspirations, perhaps, but never the less is true of what the three federal research councils are trying to do in terms of the big push for knowledge mobilisation and knowledge brokering, and etc. It's probably easier to see it in SSHRC because there's relatively little commercialization stuff there" [18-historian].

For some participants, dissemination outside of academia was considered constitutive of a professor's tasks. These individuals almost indiscriminately described a professor's role as plural, stressing its diversity of practices:

"Well whatever you do you have to sort of say what's your contribution in terms of methodology, in terms of theory, in terms of knowing about the subject, maybe politically or in terms of some sort of contribution to society or the public right. [...] I think a good [researcher] has many contributions, right, and I think that people should come to your work for a variety of reasons" [16-historian].

"Academic journals are one [way to disseminate research] but it is not the best way to do it when you want to do it here, if you want to influence the field. So, there is... I use different approaches" [2-economist - translated from French]. 
As for the incursion of the scientific field into the university field, it is made evident by the importance of research related criteria (e.g. "publish or perish") in the evaluation of colleagues for employment and promotion. In the interviews, research and teaching were often seen as complementary practices. The teaching of undergraduate courses was broadly discussed in terms of general education, while graduate seminars and student supervision were tied to the training of researchers as well as general education. Some interviewees saw teaching as secondary to their purview. One economist saw it as a drain upon research and felt that more could be delegated to course lecturers. Yet others thought it was a constitutive aspect of a professor's role. Some complained that their institution and colleagues did not put sufficient emphasis on teaching when evaluating professors. Finally, teaching was sometimes seen as a form of public intervention that draws upon research:

"I have the impression, after thirty years, that the biggest impact I probably have in the end is the students, that did not necessarily become academics, but worked in the public service, became politicians, and were - you think and sometime you see it - impacted by what they saw in university $[\ldots]$. And it is your research projects that have permitted you to transmit to them a coherence and training, and a capacity to see the world differently" [6-sociologist - translated from French].

Depending on where they stand researchers gave meaning to their practices with categories relative to the goals and stakes of scientific, university, and societal fields. Each field entertains its own internal logic in which certain practices are embedded, but these practices also borrow goals from other fields. Individuals who are actively engaged in activities in more than one field were more likely to argue in favour of the plurality of a professor's roles.

\section{Field dynamics and disciplinary practices}

\section{Research and dissemination in academia}

In the scientific field, research and dissemination are imbedded in an interaction between innovation and control. To be recognized, a contribution must claim to be novel, but it must also convince a specific peer group that it is pertinent, significant, and tailored to their norms and standards (Whitley 2000). As such, new entrants in the field can be confronted with a tension between novelty and continuity: 
"So I am always under the impression that what I do is a little beside the mark [...]. I am always a little in this and a little in that, without ever really being immersed in a debate. So, with the potential of being more original maybe, not necessarily, to make a contribution, but also with the risk that in the end nobody really takes you seriously because you are not really in the debate" [3-sociologist - translated from French].

Novelty strategies were understood by interviewees in various ways, and the meaning of a contribution varied significantly. One can claim to use a different framework, new data, or new techniques. A subject of inquiry can be framed as significant and understudied. Existing positions can be shown to be faulty or incomplete. Regardless of the strategy, the stake is to show one's distinction while simultaneously remaining sufficiently similar to be taken seriously, to have germane discussions, and to acquire recognition. As philosophers such as Kuhn (1970) have noted, a discipline implies discipline (i.e. the following of certain rules at least through exemplars). Fellow competitors in the field exercise control by determining whether an intervention is worthy of recognition and "task outcomes have to fit with the aims and skills of others if they are to be highly regarded" (Whitley 2000: 12). The interviews illustrate how this recognition can take various forms. It can generate social capital when it permits the inclusion of the researcher as an interlocutor within a network of peers:

"I would say that, again as a new prof, I have to establish myself with other experts, other historians" [1-historian - translated from French].

It can become symbolic capital when the extension of this recognition within the network coalesces into a positive reputation:

"I managed to get into it at a relatively early stage when the field was still developing. So I think it's probably fair to say I made a modest contribution to the development of the field. Particularly looking at [object], that's probably where I made my name" [23-historian].

Recognition can provide economic capital through its value in grant competitions as well as in employment and promotion:

"It's only now, I mean as a full tenured professor with a good reputation, I don't have to publish as much as I used to. So I tend to pick and choose a bit more and not rush things into print, but there are a couple things I need to get out otherwise I won't get my next SSHRC grant" [19-historian]. 
However, all of these transactions and substitutions necessitate the accumulation and renewal of sufficient scientific cultural capital to understand a field of study and to produce a contribution:

"I read enough to make it clear to myself that I am not neglecting any important literature, that I know enough about the field, and it has a price in a sense that, you know, if you're going to a totally different field... It's a high cost of... you know.... you have to do a lot there to make a serious [contribution]" [12-sociologist].

The high level of independence granted to university professors means that they exhibit different propensities to stay within a field or to move between areas of study. However, costs in cultural capital (background knowledge), social capital (contacts and recognition), and symbolic capital (reputation and label of expertise) were often tied to pressures towards specialisation. Because of these costs, this historian can formulate a strategy where expressing a diversity of interests amounts to a show of competence:

"There's a certain impulse in there that made me... you know, that came from wanting to demonstrate to my peers that I am not a one trick pony, you know, that I can write history in different styles, I can do different kinds of history" [10-historian].

Academic research and dissemination as well as much of these exchanges of recognition were often described by interviewees as taking place within "communities of interest". These were framed as conditions for research collaborations, but also for academic discussion. This is expressive of how the interplays between novelty and continuity construct discursive communities which are visible as "problematic networks" when tracking citations (De Bellis 2009: 149). Interviewees described these networks on a subjective level by using metaphors like "waves", "fronts", "dialogues", and also concepts like "invisible colleges" or "normal science".

The meaning of these discursive structures can be different and the reason for their differentiation can range from specialization to the divergence of mutually incompatible or incommensurable research endeavours. In other words, different innovation strategies can be anchored in distinct continuities, thus crafting differentiated spaces of discourse. It is exactly in this sense that Burawoy's critical sociology (and Morrow's social theory for that matter) must be understood as yet another professional sociology and not as a distinct practice. The distinction is better understood as deriving from diverging spaces of discourse (i.e. specialization) rather than distinct organisations of knowledge produc- 
tion. Indeed, specialization is not only thematic. It can take the form of parallel research traditions in response to fundamental theoretical and epistemological discordances (Whitley 2000). This differentiation of discourse may derive from distinct traditions in locales of employment and training (Davies 2009), and as the following excerpts suggest, it may also originate from choices in publication and citation:

"The vast majority of academic journals in economics are neoclassical economics. That is to say, there is a language and, seamlessly, certain methods and certain conceptual tools that need to be adopted. Otherwise it is not considered economics" [25-economist - translated from French].

"It's certain you have journals like AJS or ASR, you know, who are the strong journals of American sociology. But if you look at the articles in there it's all the same pattern, you know. There is a certain code where you take micro-problems with a big methodological apparatus and a big survey, and you derive certain hypothesis from this which you test, you know. But that, I have nothing against that, it is very good sociology, but sociology it is not just that" [21-sociologist - translated from French].

Both research and dissemination in academia incorporate a disciplinary logic regardless of whether they are labelled as professional sociology, critical sociology, or social theory. They are the products of normal processes and struggles within the scientific field through which novelty strategies are defined, contested, and nested within distinct spheres of continuity and control. Even meta-discourse is not extra-discourse. Defining the stakes and aims of scientific struggles is part of the stakes of the scientific field. Those who dominate this field have been successful in imposing what they "have, are, and do" as exemplars of science (Bourdieu 1975: 96).

\section{Research and dissemination outside academia}

Interviewees often thought of tasks relative to public discourse and expertise as secondary to academic publication. As with teaching, however, a greater emphasis on extra-academic research and dissemination was accompanied with a defense of the diversity of a professor's roles. As noted above, discourse about these practices share a propensity to borrow categories from the stakes and aims of other fields. Public dissemination as well as partnerships with government or other social actors do not, however, entail an abandonment of academic concerns. First, cultural and symbolic resources from academia were perceived by interviewees as valuable for both public dissemination and contractual endeavours: 
"Well on the immediate level my research gives me the material to write about in my blogs, or in my newspaper column, or in my lectures. And it gives me the expertise to be able to speak, when I am advising on community institutions, or when I am helping explain something for, you know, people who are going to testify" [8-historian].

"I had always tried to contribute to Op-ed pages and letters to the editor. Although before I had my doctorate nobody ever printed them [laugh]. It helps to have a doctorate and to have a name" [8-historian].

"In order to translate the research into something that's helpful you need to get the attention of the policymakers, right [...]. So then you have to build up your own career to be, you know, influential so that they come to you, right. And that means also having the right connections, and knowing the right people, and getting publicity for your work, which then means having to do really good scholarship so that people come to you and recognize you as an expert in $\mathrm{x}, \mathrm{y}$ and $\mathrm{z}$ "[13-sociologist].

Second, it is well documented that knowledge production can be simultaneously guided by fundamental and instrumental concerns (e.g. Stokes 1997). If they publish in academic journals, applied researchers are simply using different resources for knowledge production. According to interviewees, partnerships provide valuable resources to researchers through pay, research funds, access to data, or mutual learning. Partners typically negotiate research questions, and may constrain the language, tone, and preoccupations of reports and presentations. However, in most cases the researcher is free, after a period of probation, to adjust their findings to academic problems and standards to also publish in scientific journals. The synergy between applied research and academic publishing was evident when the interviewee's field of specialty was itself oriented towards application (e.g. social work, public policy) or community outreach (e.g. oral and public history).

Nonetheless, there are different ways in which interviewees described extra-academic dissemination. Research legitimated with reference to goals such as informing decision making and ensuring evidence based policy were typically framed as serving to understand situations, hierarchize objectives, and develop or evaluate programs. Contractual relations with government agencies, organizations, institutes, think tanks, or other partners can imply the production of reports or participation at workshops or panels, which were sometimes described as being motivated by instrumental issues: 
"Usually if I am going to talk to an NGO I'll try to set off some time and talk to them in an independent forum because they have survival in mind, they have service implementation issues in mind, and that may not be of interest to a general audience" [20-sociologist].

"When you are working with the organisation it is far more about recruitment, insurance, accounting... The questions are far more practical" [21-sociologist - translated from French].

In contrast, other outputs were not described as seeking to inform procedures, but rather to change or enrich perspectives. This was occasionally framed as a form of reflexivity, and was sometimes accompanied by a political agenda:

"I would rather use the word enlighten. To say, listen, what we do in the social sciences or in sociology... we do not have answers, however, we can broaden the perspectives from which problems are conceived, and we can imagine that the world is transformed because of this, in a direction that is better" [6-sociologist - translated from French].

"We were trying to historicize and relativize for what I think we sort of instinctively felt was the common good. I suppose you could say it was a left wing protest, I don't know" [22-historian].

However, public discourse of this kind takes on a more generic meaning when one understands it as a way to consolidate, transform, enrich, or complicate the perspectives of social actors. This interpretation was common when the intellectual was portrayed as providing analysis and commentary that seeks to shape how actors perceive their environment:

"It is the information to give people the perspective that is the most important to me [...]. It's much more important to me; being able to intervene in society and be able to give people some perspective and a new way of thinking" [8-historian].

General education was discussed in these terms. University teaching is institutionally distinct from public dissemination (Kalleberg 2012). However, Burawoy (2005a) is right in underlining a parallel between teaching and public discourse:

"I want to provide a certain expertise to help people today interpret, understand the events of today. So for my students, and for society at large, I try first of all maybe to complicate the questions of today because politicians always simplifies them, but secondly to propose or to provoke thoughts to find solutions" [1-historian - translated from French]. 
The classical distinction between intellectual interventions and expertise is helpful in highlighting some of the differences in how interviewees described disciplinary practices. Expertise can be understood as informing decisions by providing knowledge derived from the "cognitive authority" of science (see also Turner 2001). Other interventions enrich the knowledge that constructs the perspectives of social actors. Expertise and intellectual interventions do not correspond to distinct forms of knowledge production; one being concrete and instrumental, the other discursive and reflexive. For instance, policy relevant knowledge can be seen as informing policy and transforming perspectives:

"You can influence or you can contribute at different levels, be that at the political level, at the level of the communities, at the level of the media, at the level of research, at the level of contracts... and I do a bit of everything" [2-economist - translated from French].

Likewise, a historical analysis can be interpreted both as a way to make "public issues out of private troubles" (Burawoy 2005a: 5) or as a call to modify policy by framing issues differently:

"It is political, [...] because in the abstract, you know, in the aggregate you can say well things are all fine, but then when you break it down you realize that someone pays a price right, and we should be at least aware of that you know. And there's maybe ways to mitigate impact and so I talk a lot about that. So there's definitely a public policy dimension right, but it's not... but it's within that sort of historical framing I guess" [16-historian].

Community-based research was discussed by this oral historian as having diverse outputs, with implications for scholarship, public education, and media exposure:
"So the purpose is not just the book I am writing. Like the last book I wrote, all the interviews went to the community that I was studying. [...]. The photographer has a permanent exhibition in the community; there was an eight page article in the local paper [...]. We've done an online memory scape or online tour of the place. And so it's many pronged right and each has a different purpose, and so it's not just repeating the same thing right that is in my book" [16-historian].

Dissemination and public discourse programs are not intrinsically moral or reflexive, just like the knowledge of expert programs is not limited to instrumental concerns. This is simply the language used to legitimate them. By showing that they can either guide decision making or shape perspectives, disciplinary practices become recognizable as meaningful interventions outside of academia. It is in this sense that disciplinary 
tasks must be understood as social manoeuvers. They are distinct ways of utilizing and legitimating research.

However, different controls associated with these modes of intervention can discriminate between forms of knowledge. In societies where knowledge within the horizon of science is the most authoritative mode of understanding (at least in theory), authoritative expertise must at least maintain the appearance of stringency by deleting or masking normative opinions and by conforming to implicit and explicit standards (e.g. using statistical data can be a minimum in some contexts). Other forms of knowledge (e.g. informed intellectual commentary, historical analysis, and accounts of lived experiences, among others) do not invoke authority in decision-making, but are instead legitimated on the ground that they can shape people's general understanding of both practical and political issues. They operate more easily where different controls exist, in spaces of academic and public discourse that are removed from the centers of power (especially if they offer particularly radical interpretations). This division of labour is in part due to the spreading of the scientific ethos (Berthelot 2008). It is also congruent with the distribution of power in society and with competition between intellectuals which over the course of the $19^{\text {th }}$ and $20^{\text {th }}$ century has resulted in a gradual depreciation of less specialized forms of intervention (Sapiro 2009).

\section{Conclusion}

Drawing on sociological literature, I have grounded knowledge production and dissemination practices in discursive networks, institutes of higher learning, and forums for intellectual interventions and expertise. Subsequently, the empirical section of this paper has shown how different disciplinary practices should be regard as discrete social manoeuvers or ways of utilizing and legitimating knowledge. Although some forms of knowledge are better equipped for certain tasks, it depends on the definitions of legitimate interventions that prevail in specific social fields at any given time. Identical ways of knowing can in different settings be framed as contributions to academic debates, discourse to enlighten the perspectives of social actors, or evidence and knowhow on which to base policy and action. These interventions then influence what will be regarded as good science, good expertise, and good intellectual interventions.

More research is still required to generate finer distinctions between disciplinary practices. For example, some researchers try to empower communities by providing knowledge they can use themselves. Simi- 
larly, publication practices in different disciplines and institutional settings can significantly alter the meaning of scientific authorship (Pontille 2004). New competing ways of utilizing knowledge can be advanced and accepted or contested without fundamentally altering the social organisation of knowledge production.

The comparative advantage of this framework is that it offers more realistic and flexible parameters while accommodating a greater range of historical and sociological contexts. Instead of scrutinizing the past for sociology's essential link to civil society, we can engage in historical and sociological analysis and describe how the relationships that disciplines entertain with different fields have evolved. Likewise, instead of looking for predefined functions of distinct forms of knowledge, we can describe how epistemic styles compete and take on various functions in different contexts. This use of field theory is also compatible with ongoing interrogations in the sociology of science, expertise, and intellectuals. How do research programs become institutionalised, and how do they compete, interact, and evolve (e.g. Warren and Gingras 2007)? Whose knowledge is regarded as legitimate expertise by policymakers and stakeholders (e.g. Collins and Evans 2002)? How does knowledge produced by different groups fare in the media and in other public forums (e.g. Jacobs and Townsley 2011)?

Burawoy's model of sociology's division of labour was designed to enable and justify the ongoing development of the discipline's critical wing both inside and outside of academia. I am not denying the pertinence of such a disciplinary program. However, I hope that the approach I have presented can encourage more research and allow for a fuller understanding of the limits and the possibilities of a broader range of academic and public research and dissemination practices in the social sciences.

\section{REFERENCES}

Acker, Joan. 2005. "Comments on Burawoy on Public Sociology." Critical Sociology 31(3):327-32.

Abbott, Andrew. 2007. "For Humanist Sociology." Pp. 195-209 in Public Sociology: Fifteen Eminent Sociologists Debate Politics and the Profession in the Twenty-First Century, edited by Dan Clawson et al. Berkeley, Los Angeles, London: University of California Press.

Baiocchi, Gianpaolo. 2005. "Interrogating Connections: From Public Criticisms to Critical Publics in Burawoy's Public Sociology." Critical Sociology 31(3):339-52. 
Beck, Ulrich. 2005. "How Not to Become a Museum Piece." The British Journal of Sociology 56(3):335-43.

Berthelot, Jean-Michel. 2008. L'emprise Du Vrai: Connaissance Scientifique et Modernité. Paris: Presses universitaires de France.

Böhme, Gernot, Wolfgang Van Den Daele, and Wolfgang Krohn. 1976. "Finalization in Science." Social Science Information 15(2-3):307-30.

Bourdieu, Pierre. 1975. "La Spécificité Du Champ Scientifique et Les Conditions Sociales Du Progrès de La Raison.” Sociologie et sociétés 7(1):91.

Bourdieu, Pierre. 1999. "Le Fonctionnement Du Champ Intellectuel.” Regards sociologiques (17-18):5-27.

Bourdieu, Pierre. 2011. "Champ du pouvoir et division du travail de domination." Actes de la recherche en sciences sociales 190(5):126-39.

Boyns, David and M. A. Jesse Fletcher. 2005. "Reflections on Public Sociology: Public Relations, Disciplinary Identity, and the Strong Program in Professional Sociology.” The American Sociologist 36(3-4):5-26.

Brady, David. 2004. "Why Public Sociology May Fail." Social Forces 82(4):1629-38.

Braithwaite, John. 2005. "For Public Social Science." The British Journal of Sociology 56(3):345-53.

Brewer, Rose M. 2005. "Response to Michael Buroway's Commentary: 'The Critical Turn to Public Sociology."” Critical Sociology 31(3):353-60.

Brint, Steven. 2005. "Guide for the Perplexed: On Michael Burawoy's 'public Sociology."” The American Sociologist 36(3):46-65.

Brooks, Stephen, and Alain Gagnon. 1994. Les spécialistes des sciences sociales et la politique au Canada: entre l'ordre des clercs et l'avant-garde. Montreal: Boréal.

Brym, Robert Joseph, and M. Reza Nakhaie. 2009. "Professional, Critical, Policy, and Public Academics in Canada." Canadian Journal of Sociology 34(3):655-70.

Burawoy, Michael et al. 2004. "Public Sociologies: A Symposium from Boston College.” Social Problems 51(1):103-30.

Burawoy, Michael. 2004. "Public Sociologies: Contradictions, Dilemmas, and Possibilities." Social Forces 82(4):1603-18.

Burawoy, Michael. 2005a. "2004 ASA Presidential Address: For Public Sociology.” American Sociological Review 70(1):4-28.

Burawoy, Michael. 2005b. "The Critical Turn to Public Sociology." Critical Sociology 31(3):313-26.

Burawoy, Michael. 2005c. "Third-Wave Sociology and the End of Pure Science." The American Sociologist 36(3):152-65. 
Burawoy, Michael. 2007. "The Field of Sociology." Pp. 241-58 in Public Sociology: Fifteen Eminent Sociologists Debate Politics and the Profession in the Twenty-First Century, edited by Dan Clawson et al. Berkeley, Los Angeles, London: University of California Press.

Burawoy, Michael. 2009a. "Disciplinary Mosaic: The Case of Canadian Sociology." Canadian Journal of Sociology 34(3):869-86.

Burawoy, Michael. 2009b. "Public Sociology in the Age of Obama." Innovation: The European Journal of Social Science Research 22(2):189-99.

Burawoy, Michael. 2010. "Southern Windmill: The Life and Work of Edward Webster." Transformation: Critical Perspectives on Southern Africa 72(1): $1-25$.

Calhoun, Craig. 2005. "The Promise of Public Sociology." The British Journal of Sociology 56(3):355-63.

Clemens, Elisabeth S., Walter W. Powell, Kris McIlwaine, and Dina Okamoto. 1995. "Careers in Print: Books, Journals, and Scholarly Reputations." American Journal of Sociology 101(2):433-94.

Collins, Harry M., and Robert Evans. 2002. "The Third Wave of Science Studies Studies of Expertise and Experience." Social Studies of Science 32(2):235-96.

Collins, Patricia H. 2007. "Going Public: Doing the Sociology That Had No Name." Pp. 101-13 in Public Sociology: Fifteen Eminent Sociologists Debate Politics and the Profession in the Twenty-First Century, edited by Dan Clawson et al. Berkeley, Los Angeles, London: University of California Press.

Creese, Gillian, Arlene Tigar McLaren, and Jane Pulkingham. 2009. "Rethinking Burawoy: Reflections from Canadian Feminist Sociology." Canadian Journal of Sociology 34(3):601-22.

Davies, Scott. 2009. "Drifting Apart? The Institutional Dynamics Awaiting Public Sociology in Canada." Canadian Journal of Sociology 34(3):623-54.

De Bellis, Nicola. 2009. Bibliometrics and Citation Analysis from the Science Citation Index to Cybermetrics. Lanham, Md.: Scarecrow Press.

Ericson, Richard. 2005. "Publicizing Sociology." The British Journal of Sociology 56(3):365-72.

Etzkowitz, Henry, and Loet Leydesdorff. 2000. "The Dynamics of Innovation: From National Systems and 'Mode 2' to a Triple Helix of University-industry-government Relations." Research Policy 29(2):109-23.

Fournier, Marcel. 1985. "La Sociologie Dans Tous Ses États.” Recherches sociographiques 26(3):417.

Ghamari-Tabrizi, Behrooz. 2005. "Can Burawoy Make Everybody Happy? Comments on Public Sociology.” Critical Sociology 31(3):361-70. 
Gibbons, Michael et al. 1994. The New Production of Knowledge: The Dynamics of Science and Research in Contemporary Societies. SAGE Publications Limited.

Gingras, Yves. 1991. "L'institutionnalisation de La Recherche En Milieu Universitaire et Ses Effets." Sociologie et sociétés 23(1):41.

Gingras, Yves, and Brigitte Gemme. 2006. "L'emprise Du Champ Scientifique Sur Le Champ Universitaire et Ses Effets." Actes de la recherche en sciences sociales (4):51-60.

Gingras, Yves, and Jean-Philippe Warren. 2006. “A British Connection? A Quantitative Analysis of the Changing Relations between American, British and Canadian Sociologists." The Canadian Journal of Sociology / Cahiers canadiens de sociologie 31(4):509-22.

Glenn, Evelyn N. 2007. "Whose Public Sociology? The Subaltern Speaks, but Who Is Listening?" Pp. 213-29 in Public Sociology: Fifteen Eminent Sociologists Debate Politics and the Profession in the Twenty-First Century, edited by Dan Clawson et al. Berkeley, Los Angeles, London: University of California Press.

Godin, Benoît. 2002. "Les Pratiques de Publication Des Chercheurs: Les Revues Savantes Québécoises Entre Impact National et Visibilité Internationale." Recherches sociographiques 43(3):465-98.

Goldberg, Avi and Axel van den Berg. 2009. "What Do Public Sociologists Do? A Critique of Burawoy." Canadian Journal of Sociology 34(3):765-802.

Hall, John A. 2005. "A Guarded Welcome.” The British Journal of Sociology 56(3):379-81.

Hamel, Jacques. 2006. "Décrire, Comprendre et Expliquer. Réflexions et Illustrations En Sociologie." SociologieS 1(1):1-14.

Hays, Sharon. 2007. "Stalled at the Altar. Conflict, Hierarchy, and Compartmentalization in Burawoy's Public Sociology." Pp. 79-90 in Public Sociology: Fifteen Eminent Sociologists Debate Politics and the Profession in the Twenty-First Century, edited by Dan Clawson et al. Berkeley, Los Angeles, London: University of California Press.

Helmes-Hayes, Richard. 2009. "Engaged, Practical Intellectualism: John Porter and 'new Liberal'public Sociology." Canadian Journal of Sociology 34(3):831-68.

Jacobs, Ronald N., and Eleanor R. Townsley. 2011. The Space of Opinion: Media Intellectuals and the Public Sphere. New York: Oxford University Press, USA.

Kalleberg, Ragnvald. 2000. "Universities: Complex Bundle Institutions and The Project of Enlightenment." Pp. 219-55 in Comparative Perpectives on Universities, edited by Ragnvald Kalleberg, Fredrick. Engelstad, Grete Brochmann, Arnlaug Leira, and Lars Mjøset. Stamford, Connecticut: Jai Press Inc. 
Kalleberg, Ragnvald. 2005. "What Is 'Public Sociology'? Why and How Should It Be Made Stronger?” The British Journal of Sociology 56(3):387-93.

Kalleberg, Ragnvald. 2012. "Sociologists as Public Intellectuals and Experts." Journal of Applied Social Science 6(1):43-52.

Katz-Fishman, Walda, and Jerome Scott. 2005. "Comments on Burawoy: A View From the Bottom-Up." Critical Sociology 31(3):371-74.

Knobloch-Westerwick, S., C. J. Glynn, and M. Huge. 2013. "The Matilda Effect in Science Communication: An Experiment on Gender Bias in Publication Quality Perceptions and Collaboration Interest." Science Communication 35(5):603-25.

Kowalchuk, Lisa, and Neil McLaughlin. 2009. "Mapping the Social Space of Opinion: Public Sociology and the Op-Ed in Canada." Canadian Journal of Sociology 34(3):697-728.

Kuhn, Thomas S. 1970. The Structure of Scientific Revolutions. Chicago: University of Chicago Press.

Lincoln, A. E., S. Pincus, J. B. Koster, and P. S. Leboy. 2012. "The Matilda Effect in Science: Awards and Prizes in the US, 1990s and 2000s." Social Studies of Science 42(2):307-20.

Mallard, Grégoire, Michèle Lamont, and Joshua Guetzkow. 2009. "Fairness as Appropriateness Negotiating Epistemological Differences in Peer Review." Science, Technology \& Human Values 34(5):573-606.

Massey, Douglas. 2007. "The Strength of Weak Politics." Pp. 145-57 in Public Sociology: Fifteen Eminent Sociologists Debate Politics and the Profession in the Twenty-First Century, edited by Dan Clawson et al. Berkeley, Los Angeles, London: University of California Press.

McLaughlin, Neil. 2005. "Canada's Impossible Science: Historical and Institutional Origins of the Coming Crisis in Anglo-Canadian Sociology." The Canadian Journal of Sociology 30(1):1-40.

McLaughlin, Neil, Lisa Kowalchuk, and Kerry Turcotte. 2005. "Why Sociology Does Not Need to Be Saved: Analytic Reflections on Public Sociologies." The American Sociologist 36(3-4):133-51.

McLaughlin, Neil, and Kerry Turcotte. 2007. "The Trouble with Burawoy: An Analytic, Synthetic Alternative." Sociology 41(5):813-28.

Medvetz, Thomas. 2012. Think Tanks in America. Chicago: University of Chicago Press.

Mesny, Anne. 2009. "What Do 'we'know That 'they'don't? Sociologists' versus Non-Sociologists' Knowledge.” Canadian Journal of Sociology 34(3):671-96.

Mochnacki, Alex, Aaron Segaert, and Neil Mclaughlin. 2009. "Public Sociology in Print: A Comparative Analysis of Book Publishing in Three Social Science Disciplines." Canadian Journal of Sociology 34(3):729-64. 
Morrow, Raymond A. 2009. "Rethinking Burawoy's Public Sociology: A PostEmpiricist Reconstruction.” Pp. 47-69 in Handbook of public sociology, edited by Vincent Jeffries. Lanham, Md.: Rowman \& Littlefield Publishers.

Nielsen, Francois. 2004. "The Vacant' We': Remarks on Public Sociology.” Social Forces 82(4):1619-27.

Nowotny, Helga, Peter Scott, and Michael Gibbons. 2001. Re-Thinking Science: Knowledge and the Public in an Age of Uncertainty. Cambridge, UK: Polity.

Patterson, Orlando. 2007. "About Public Sociology." Pp. 176-94 in Public Sociology: Fifteen Eminent Sociologists Debate Politics and the Profession in the Twenty-First Century, edited by Dan Clawson et al. Berkeley, Los Angeles, London: University of California Press.

Piven, Frances F. 2007. "From Public Sociology to Politicized Sociologist." Pp. 158-66 in Public Sociology: Fifteen Eminent Sociologists Debate Politics and the Profession in the Twenty-First Century, edited by Dan Clawson et al. Berkeley, Los Angeles, London: University of California Press.

Pontille, David. 2004. La signature scientifique: une sociologie pragmatique de l'attribution. Paris: CNRS.

Sabourin, Paul. 2003. "L'analyse de Contenu." Pp. 357-85 in Recherche sociale: de la problématique à la collecte des données, edited by Benoît Gauthier. Sainte-Foy: Presses de l'Université du Québec.

Sapiro, Gisèle. 2009. "Modèles d'intervention politique des intellectuels." Actes de la recherche en sciences sociales 176-177(1):8-31.

Smith-Lovin, Lynn. 2007. "Do We Need a Public Sociology? It Depends on What You Mean by Sociology." Pp. 124-34 in Public Sociology: Fifteen Eminent Sociologists Debate Politics and the Profession in the TwentyFirst Century, edited by Dan Clawson et al. Berkeley, Los Angeles, London: University of California Press.

Sprague, Joey and Heather Laube. 2009. "Institutional Barriers to Doing Public Sociology: Experiences of Feminists in the Academy." The American Sociologist 40(4):249-71.

Stacey, Judith. 2007. "If I Were the Goddess of Sociological Things." Pp. 91-100 in Public Sociology: Fifteen Eminent Sociologists Debate Politics and the Profession in the Twenty-First Century, edited by Dan Clawson et al. Berkeley, Los Angeles, London: University of California Press.

Stinchcombe, Arthur. 2007. "Speaking Truth to the Public, and Indirectly to Power." Pp. 135-44 in Public Sociology: Fifteen Eminent Sociologists Debate Politics and the Profession in the Twenty-First Century, edited by Dan Clawson et al. Berkeley, Los Angeles, London: University of California Press.

Stack, Steven. 2004. "Gender, Children and Research Productivity." Research in Higher Education 45(8):891-920. 
Stokes, Donald E. 1997. Pasteur's Quadrant: Basic Science and Technological Innovation. Washington, D.C.: Brookings Institution Press.

Tittle, Charles R. 2004. "The Arrogance of Public Sociology." Social Forces 82(4):1639-43.

Turner, R. Steven. 1971. "The Growth of Professorial Research in Prussia, 1818 to 1848-Causes and Context." Historical Studies in the Physical Sciences 3:137-82.

Turner, Jonathan H. 2005. "Is Public Sociology Such a Good Idea?" The American Sociologist 36(3-4):27-45.

Turner, Stephen. 2001. "What is the Problem with Experts?" Social Studies of Science 31(1):123-149.

Wallerstein, Immanuel. 2007. "The Sociologist and the Public Sphere.” Pp. 16975 in Public Sociology: Fifteen Eminent Sociologists Debate Politics and the Profession in the Twenty-First Century, edited by Dan Clawson et al. Berkeley, Los Angeles, London: University of California Press.

Warren, Jean-Philippe. 2009. "The Three Axes of Sociological Practice: The Case of French Quebec." Canadian Journal of Sociology 34(3):803-30.

Warren, Jean-Philippe, and Yves Gingras. 2007. "Introduction. Between Society and University: Humanities and Social Sciences in Canada." Scientia Canadensis: Canadian Journal of the History of Science, Technology and Medicine 30(2):1.

Wennerås, Christine, and Agnes Wold. 1997. "Nepotism and Sexism in Peer Review." Nature 387(6631):341-43.

Whitley, Richard. 2000. The Intellectual and Social Organization of the Sciences. 2nd ed. Oxford: Oxford Univ. Press.

Wittrock, Björn. 2003. "History of Social Science: Understanding Modernity and Rethinking Social Studies of Science." Pp. 79-101 in Social Studies of Science and Technology: Looking Back, Ahead, edited by Bernward Joerges and Helga Nowotny. Dordrecht: Kluwer Academic Publishers.

Julien Landry is a $\mathrm{PhD}$ candidate in Science, Technology and Society at l'Université du Québec à Montréal. His research intersects political sociology and the sociology of expertise. More specifically, he focuses on the social sciences and their use in public debate and policy making. He is currently studying the history and structure of the think tank landscape in Canada.

jlandry_06@hotmail.com 